ISSN No. 0974-035X

An Indexed, Refereed \& Peer Reviewed Journal of Higher Education

\title{
Existentialism in For Whom the Bell Tolls
}

\author{
Dr. Jagdish Joshi
}

\section{Saurabh R. Vaishnav}

\section{Introduction}

As the scientific and industrial revolutions came to a head in the 19th century, and society became increasingly secularized, the traditional social order underwent radical change in a very short time. During this period, people began to feel disconnected from the traditional belief systems that had helped them make sense of the world and of their lives. In these conditions, people may not literally commit suicide, but a kind of spiritual death - spiritual death - becomes a real danger. It occurs when people give up to resignation and surrender in the face of what they see as the pointlessness of existence.

Existentialism is the philosophy that recognizes this problem and attempts to address it. It is a philosophy that makes an authentically human life possible in a meaningless and absurd world. The belief that people are searching to find out who and what they are throughout life as they make choices based on their experiences, beliefs, and outlook without the help of laws, ethnic rules, or traditions. Existentialism thus became fashionable in the post-World War years as a way to reassert the importance of human individuality and freedom. 
Existentialism often has a connotation of a being a particularly gloomy philosophy, one that is obsessed with the notions of anxiety and dread. So, the first thing to say is existentialism is actually a very invigorating and positive minded philosophy. The message of existentialism is that every one of us, as an individual, is responsible - responsible for what we do, responsible for who we are, responsible for the way we face and deal with the world, responsible, ultimately, for the way the world is (Wartenberg 102).

Life may be difficult, circumstances may be impossible. There may be obstacles, not because of our personalities, characters, emotions, and limited means or intelligence. But, nevertheless, we are responsible. We cannot shift that burden onto God, or nature, or the ways of the world. If there is a God, we may believe him. If nature made us one way, it is up to us to decide what we are to do with what nature gives us - whether to go along or fight back, to modify or transcend nature. As Kate Hepburn says to Humphrey Bogart in the movie The African Queen, "Nature is what we are put on this earth, to rise above".

\section{For Whom the Bell Tolls}

High in the pine forests of the Spanish Sierra, a guerilla band prepares to blow up a vital bridge. Robert Jordan, a young American volunteer, has been sent to handle the dynamiting. There, in the mountains, he finds the dangers and the intense comradeship of war. And there he discovers Maria, a young woman who has escaped from Franco's rebels. When For Whom the Bell Tolls was published in 1940, it immediately became a resounding critical and popular success and helped cement Ernest Hemingway's reputation as one of America's foremost writers. Readers praised its realistic portrait of not only the political tensions in Europe that would soon erupt into World War II but also the March, 2019. VOL.11. ISSUE NO. 1

$\underline{\text { www.hrdcgujarat.ac.in }}$

Page $\mid 10$ 
complexities of the entire experience of war for the individual who found him or herself fighting for a cause.

Robert Jordan in For Whom the Bell Tolls shares a number of existentialism traits viz. responsibility, awareness of death, freedom and individuality. In the research paper, Robert Jordan will be analyzed, according to various existential parameters.

\section{Responsibility in For Whom the Bell Tolls}

A demolitions expert, Jordan is obedient and self-sacrificing to a fault, blowing up trains or bridges for the Republican Cause, even when he starts, as a result of his relationship with Maria, to question its very legitimacy. His dedication is beyond reproach and although he has thoughts that the Cause might not be worth sacrificing himself and the others, especially Maria, he easily disregards his thoughts of a happy future with her and over and over again convinces himself that his purpose is sound. Even at the end, he thinks how proud he would have made his grandfather. Indeed, even when he realizes that destroying the bridge could be carried out in a manner less detrimental to human life than originally planned by the Russian General Golz, he never changes the script, so to speak, and proceeds with his commanders' orders.

Jordan attempts to come to terms with the orders that Golz gave him. He is resentful but realizes how important his and Anselmos's roles are in winning the war. "You are instruments to do your duty. There are necessary orders that are no fault of yours and there is a bridge and that bridge can be the point on which the future of the human race can turn. As it can on everything that 
happens in this war. You have only one thing to do and you must do it." (Hemingway 43)

The highly idealistic Jordan doesn't care for hunting but doesn't hesitate to kill a man if it will benefit the republican Cause, or if the means justify the end. But, Jordan is misguided. Through this character, Hemingway points out how 77 people can be blinded by what they think of as worthwhile. Thus, the protagonist Jordan illustrates how war can bring about great harm by wellmeaning, albeit ignorant, individuals.

\section{Awareness of Death in For Whom the Bell Tolls}

"No man is an Island, entire of it selfe; every man is a piece of the Continent, a part of the maine; if a Clod be washed away by the Sea,_Europe is the lesse, as well as if a Promontorie were, as well as if a Mannor of thy friends or of thine owne were; any mans death diminishes me, because I am involved in Mankinde; And therefore never send to know for whom the bell tolls; It tolls for thee" (Hemingway 4).

For Whom the Bell Tolls opens with an epigraph, a short quotation that introduces the novel, sets the mood, and presents a theme. This epigraph is from a short essay by the seventeenth-century British poet John Donne. Donne writes that no person stands alone--No man is an island, entire of itself $\|$-because everyone belongs to a community. As a result, the death of any human diminishes Donne himself because he is a part of mankind. Donne admonishes us not to ask who has died when we hear a funeral bell toll, for it tolls for everyone in the human race. 
In chapter forty-three, considering the premonitions strewn throughout the novel, it is expected that Jordan will die. Indeed, for him not to die would be disquieting. However, it is anticipated that Jordan will die dynamiting the bridge or perhaps that Pablo will take revenge and shoot Jordan at the end of the mission. However, Hemingway surprises us with the highly ironic manner in which Jordan dies. He escapes death for a very short while only to have the omen of living life for three days fulfilled. Just when he appears safe, he suddenly dies.

As the lovers part company forever, the theme of a couple as two entities united in one is repeated. "In the last few days he had learned that he himself, with another person, could be everything that cannot be taken nor lost" (Hemingway 467). He thinks back to the Pilar's prophesies and comes to realize "there's no one thing that's true, it's all true" (Hemingway 467). Finally, in a circular fashion, the narrative returns to the beginning of the novel to an earlier scene in which Robert Jordan lies on "a pine needle floor of the forest" (Hemingway 471).

\section{Freedom in For Whom the Bell Tolls}

The epigraph makes a philosophical point that is central to the book. The idea is that no individual person is really all =on their own,' but always bound up with other people. In some way, every other person is a part of our own self, of who we really are - so when another person is lost, we lose something too. Hence the idea that whenever the bell tolls, it tolls for us - whenever somebody dies, it's as if a part of us dies. 
When one speaks of bells tolling, it usually means one thing: someone has died. This is a book with death on the mind. It's about a war, and people die in wars. But it's also a meditation on death. Because of the war situation, all of the characters face their own death, and the possibility of having to inflict death on those they are fighting against, or fighting with.

The position of Robert Jordan at the beginning of the book is actually a stage in an ongoing process of 'education.' Prior to the Robert Jordan we meet, there was Robert Jordan the die-hard leftist revolutionary. Robert Jordan compares his early experience in the war with the Communists to religion, "You felt, in spite of all bureaucracy and inefficiency and party strife, something that was like the feeling you expected to have and did not have when you made your first communion. It was a feeling of consecration to a duty toward all the oppressed of the world which would be as difficult and embarrassing to speak about as religious experience and yet it was authentic [...] It gave you a part in something that you could believe in wholly and completely and in which you felt an absolute brotherhood with the others who were engaged in it. It was something that you had never known before but that you had experienced and you gave such importance to it and the reasons for it that your own death seemed of complete unimportance; only a thing to be avoided because it would interfere with the performance of your duty. But the best thing was that there was something you could do about this feeling and this necessity too. You could fight." (Hemingway 259).

\section{Individuality in For Whom the Bell Tolls}

The protagonist of For Whom the Bell Tolls, Robert Jordan left his job as a college instructor in the United States to volunteer for the Republican side in the March, 2019. VOL.11. ISSUE NO. 1 
Spanish Civil War. Initially, he believed in the Republican cause with a nearreligious faith and felt an absolute brotherhood with his comrades on the Republican side. As the conflict drags on, he realizes that he does not really believe in the Republican cause but joined their side simply because they fought against Fascism. Because he fights for a side whose causes he does not necessarily support, Robert Jordan experiences a great deal of internal conflict and begins to wonder whether there is really any difference between the Fascist and Republican sides.

Robert Jordan's interior monologues and actions indicate these internal conflicts that plague him. Although he is disillusioned with the Republican cause, he continues to fight for that cause. In public he announces that he is antiFascist rather than a Communist, but in private he thinks that he has no politics at all. He knows that his job requires that he kill people but also knows that he should not believe in killing in the abstract. Despite his newfound love for Maria, he feels that there cannot be a place for her in his life while he also has his military work. He claims not to be superstitious but cannot stop thinking about the world as giving him signs of things to come. These conflicts weigh heavily on Robert Jordan throughout the bulk of the novel.

Robert Jordan resolves these tensions at the end of For Whom the Bell Tolls, in his final moments as he faces death. He accepts himself as a man of action rather than thought, as a man who believes in practicality rather than abstract theories. He understands that the war requires him to do some things that he does not believe in. He also realizes that, though he cannot forget the unsavory deeds he has done in the past, he must avoid dwelling on them for the sake of getting things done in the present. Ultimately, Robert Jordan is able to make 
room in his mind for both his love for Maria and his military mission. By the end of the novel, just before he dies, his internal conflicts and tensions are resolved and he feels -integrated\| into the world.

Robert Jordan just seems too unfazed by everything, too sure of himself. He doesn't seem to have strong feelings or passions, powerful motivations or attachments, no glaring flaws, and, no personality, or humanity. He supposedly loves Spain, but we can't really find any passion in it or explanation for it. As such, you could argue that he's just a bad protagonist - unbelievable and uninteresting.

\section{Conclusion}

Robert Jordan is fully aware of his responsibilities. He has undertaken the mission to blow up the Fascists bridge, and he will not hesitate to put his life on the line to complete the mission, and that is what he exactly does. He risks everything to his mission. $\mathrm{He}$ is conscious of his choices and takes responsibilities for his actions. He is a man who personifies freedom.

Life for Robert Jordan is a set of ideals which he will follow to the end. The risks that Robert Jordan undertakes are incomparable. He has actions to undertake and duties to perform. Robert Jordan here displays the element of individuality. To conquer fear and to stay calm in adversity is what Robert Jordan follows. His stoic acceptance to his fate is commendable. Life is a fight and he is the ultimate fighter. He would choose to die in courage rather than live in fear. And that is how he gives meaning to his life.

Robert Jordan's behavior and ideals are of high standards. For Whom the Bell Tolls showcases only four days of Robert Jordan's life and events that take 
place in this time span. Robert Jordan is aware of death, however he shows tremendous amount of calmness and composure. He chooses to sacrifice himself for the sake of others to give meaning to his life. He could have easily chosen to leave this highly dangerous mission and return to his country, but he chooses otherwise. It was his fate that he laid down his life while fighting for a just cause for others.

Hence, on studying the novel For Whom the Bell Tolls in the light of existentialism, it can fairly be concluded that the following elements of existentialism like: Responsibility, Anxiety, Fate, Individuality, Freedom and Awareness of death are found in the novel. Hence, existentialism is prominent in the novel. 


\section{Works Cited}

The African Queen. Dir. John Huston. Perf. Humphrey Bogart, Katharine

Hepburn, and Robert Morley. United Artists, 1952.Film.

"Awareness of death." Inner frontier. N.p., n.d. Web. 20 Dec. 2010.

Cogswell, David. Existentialism for Beginners (For Beginners). Connecticut: For Beginners, 2008. Print.

Cohn, Louis Henry. A Bibliography of the Works of Ernest Hemingway. New York: Random House, 1931. Print.

“Existentialism.” The cry. N.p., n.d. Web. 28 Nov. 2010.

“Existentialism - A philosophy." All about philosophy. N.p., n.d. Web. 30 Nov. 2010.

Flynn, Thomas. Existentialism. New York: Sterling Publishing Co., 2009. Print.

For Whom the Bell Tolls. Dir. Sam Wood. Perf. Gary Cooper and Ingrid Bergman. Paramount Pictures, 1943.Film.

“For Whom the Bell Tolls.” Novelguide.com. N.p., n.d. Web. 11 Mar. 2011.

Hemingway, Ernest. For Whom the Bell Tolls. New York: Scribner's Magazine, 1940. Print.

Panza, Christopher, and Gregory Gale. Existentialism for Dummies. Hoboken: Wiley Publishing Inc, 2008. Print. 
The African Queen.Dir. John Huston. Perf. Humphrey Bogart, Katharine Hepburn, and Robert Morley. United Artists, 1952.Film.

Wartenberg, Thomas E. Existentialism (Beginner's Guide). Oxford: Oneworld Publications, 2008. Print.

“What is existentialism?" Fortune city. N.p., n.d. Web. 27 Nov. 2010. 126

“What is Existentialism?" Narr. Robert C. Solomon. The Great Courses on Tape. No Excuses: Existentialism and the Meaning of Life. The Teaching Company, 2000. CD.

\section{Dr. Jagdish Joshi}

Professor and Director

UGC Human Resource Development Centre

Gujarat University

Ahmedabad

\section{Saurabh R. Vaishnav}

Asst Professor of English

St Xavier's College

Ahmedabad 